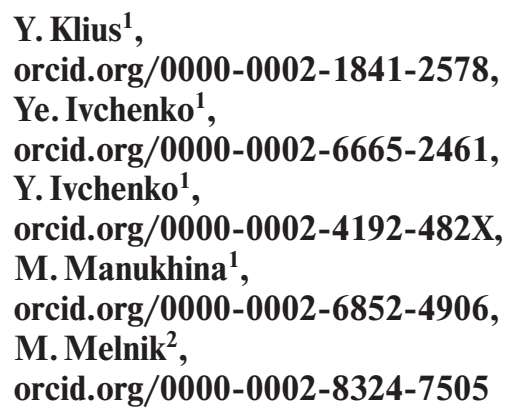

1 - Volodymyr Dahl East Ukrainian National University, Severodonetsk, Ukraine, e-mail: docentklus@gmail.com 2 - Severodonetsk Institute of Interregional Academy of Personnel Management, Severodonetsk, Ukraine

\title{
DEVELOPMENT OF THE INTEGRATED INNOVATION MANAGEMENT APPROACH AT INDUSTRIAL ENTERPRISES IN POST CONFLICT TRANSFORMATION
}

Purpose. To establish integrated innovation management based on developing a corporate innovation base at industrial enterprises in the context of post-conflict transformation.

Methodology. In the course of the works, the methods of theoretical generalization, comparison, synthesis, analysis were used to reveal the general principles and to determine the basic categories of the study.

Findings. A model of the integrated innovation management approach at industrial enterprises is developed. In modern corporate structures, innovations are divided into groups according to their independent properties. The innovation management system, if it exists, is considered as an independent system that has its own set of goals which are not integrated into the goals of the corporation itself. The paper considers the goals of innovation management in an integrated structure as the implementation of the goals of a corporation, where innovation management processes are integrated horizontally and vertically according to business processes. Innovation management is based on three approaches: transfer, algorithmic and creative ones.

Originality. The paper offers the authors' methods for managing innovation by using the system of methodological approaches (algorithmic, transfer, creative managements), based on processes of innovation management at the industrial enterprises in the context of post-conflict transformation, which have been identified applying the mathematical models. The study has developed:

- the author's approach to the formation of innovation management objectives at industrial enterprises in post-conflict transformation context, based on eight key spaces, with the identification of five groups of goals: financial, production, marketing, human resource management, and information support;

- a system of innovation management objectives with a of innovation management task subsystem in the field of financial activities, production process, marketing, human resource management and information technology support.

Practical value. The practical significance of the results is that they can be applied in corporate integration structures to increase economic efficiency, making a profit from introduction.

Keyword: innovation activity, industrial enterprise, post-conflict transformation, assessment, indicators

Introduction. The analysis of existing approaches to innovation management showed that in each approach the novation, knowledge about innovation and related processes are treated as groups of distinct formalised parameters. The innovation management system itself is considered as a practically independent system that is not bound by a common goal with the company. This approach leads to technocratic and efficient consideration of administration processes. We have developed a mathematical approach to managing innovations at an enterprise in a post-conflict transition, based on the premise that an enterprise's goals should define the goals of managing innovation, while enterprise innovation management processes should be integrated with vertical and horizontal levels of business processes in post-conflict transformation.

The goals of innovation management are determined by the organizational purpose of micro-level entities, one of the important tasks is the task of forming the goals of the organization. The enterprise's objective is the expected outcome or some future predetermined state of an object (enterprise itself, its performance indicators, business direction, functional block, production complex). The objectives of the company create an objectives tree. The objectives tree is viewed as a hierarchical, structured, level-distributed and ordered set of goals of the economic system, program, plan that defines: the general objective as the "root node"; the subordinate to it subgoals of the first level "first level nodes"; subordinate to it subgoals of the second level - "second level nodes" and others.

(c) Klius Y., Ivchenko Ye., Ivchenko Y., Manukhina M., Melnik M., 2021
The basis for building the root node and the first-level nodes are many strategic goals defined within the enterprise strategy. It is necessary to clarify that strategically important should be considered not only goals that determine the directions of strategic development, but also long-term goals associated with the support of the administration system, but also with the production and provision of the company. Achieving strategic objectives is inextricably linked to the implementation of both tactical and operational objectives. The identification, definition and hierarchy ordering of each of the objectives is carried out through a series of analytical operations as well as harmonization and approval processes, as the goal of the innovation management is linked to the purposes of the organization. Their content will depend on how the objectives of the organization are shaped.

Literature review. The literature on innovation is limitless. In 1978 more than 4000 scientific papers were reviewed on technological novation only. Since then, the number of works has increased exponentially. The analysis of the national and foreign scientists' papers reveals significant discrepancies, both in definitions and in the system of evaluating criteria for innovation, and above all in the first one. Novelty has been studied by a wide variety of disciplines - sociology, economy, history, management. Accordingly, more and more definitions of innovation have accumulated.

Many national scientists' papers study the innovative development regulation; they have significantly expanded the theoretical and methodological base and made a significant contribution to the development of an effective mechanism for 
managing innovative activities both at the state and regional levels. In particular, [1] considers the innovation policy to be a component of the state scientific, technical, general policy, in connection with which it proposes to develop a strategy for the preservation, and development of the national scientific, technical and innovative potential, based on the state regulation and incentives; and it involves the use of administrative and market regulators. According to [2], one of the priority tasks of building a mechanism for the regional novation development should be improvement of the legal and economic mechanisms for the new technologies at the state level as well as novation development and implementation. In work [3], the author identifies two directions of building and implementing the organizational and economic mechanism for the innovative development policy implementation in the region. He notes that, on the one hand, innovation policy should intensify the introduction of innovative elements in the regional development management, and on the other, ensure the development of the regions through the diffusion of innovations and the effective use of the innovative potential of the region. The author [4] considers the improvement of the local self-government system to be one of the most important conditions for the innovation processes activation at the regional level.

On the basis of the research $[5,6]$, it is possible to identify the tasks to be achieved in the formation of the innovation management system of an enterprise.

Scientists [7] consider the innovative management as a component of the modern enterprise management, including planning, organizing and stimulating innovation, the implementation of the innovative projects, designed to gain competitive advantages and strengthen the market position of the enterprise.

According to the studies [8], the innovation management system of an enterprise is a set of elements that are interlinked and influence the innovation process. The system aims to achieve its objectives within the defined innovation management principles and practices framework, and is based on the principles of systematism, dynamism, scientific soundness, unity of goals, flexibility and efficiency.

Work [9] states that the development of the management systems should be based on the principles of integrity, systematicity, hierarchy and development.

In recognition of the researchers on innovation management, it should be noted that the corporate innovation base development at enterprises has so far been studied fragmentarily. In particular, there is little knowledge in the innovation management economics in the corporate structure, as well as little research on innovation management tools in the corporate structure. The mathematical aspects of managing innovation in a company are also insufficiently researched.

Within the innovative theory framework, practical recommendations for overcoming a protracted economic depression have also been developed. They are especially relevant for the industrial enterprises in the regions that found themselves in a post-conflict transformation. The most reliable means from this point of view is the massive implementation of the basic innovations. The means may vary: passive expectation of the depression's "natural" end [10], artificial stimulation of innovation [11], implementation of the institutional changes in order not only to accelerate the recovery from the crisis, but also to prevent the crisis deepened, enable the economy to take advantage of the stimulating role of depression to spur innovation [12]. This approach was used at a stage when a strategic planning methodology existed. These processes were then relevant to strategic planning, such as implementation of the targeted approach that was proposed at that time in the paper [13].

The studies [14] identified the knowledge workers' productivity improvement and the collective knowledge rapid accumulation and use within the organization as the major innovation drivers.
According to the concept [15], organizations should create a new job unit - an innovation manager. The innovation manager has the authority to implement all existing innovation management practices in the organization. In relation to the organizational structure, the innovation management unit may be placed outside the hierarchical structure, but at the same time it should have the ability to interact with units at any level. Decisions made by the knowledge manager do not concern the use of innovation, but the process of working with it.

The scientist [16] discusses an action-oriented knowledge system that makes sense in post-conflict transformation. It consists of four elements: knowledge, explicit and implicit; knowledge of assets; confidence in the organization's success; certainty and uncertainty of decisions in relation to objectives. They are set up, together with their interactions, into thinking systems, focused on action. The Empirical School of Knowledge Management [17] describes the exploitation and transfer of knowledge between partners in strategic alliances. The school attaches great importance to explicit and implicit knowledge and asserts that the key issue is to transform implicit individual knowledge into the explicit competence of the organization.

The main disadvantage of the considered approaches is their focus on purely empirical models and practical experience.

Purpose of this research is to improve the innovation management process at the industrial enterprises in the context of post-conflict transformation by developing a mathematical basis for an integrated administration based on the creation of a corporate novation base at an enterprise.

To achieve the goal, the following tasks were set:

- to develop the proprietary research methodology, that considers innovation management in the methodological approach system;

- to analyse approaches to the innovation management objectives formation at industrial enterprises in the context of post-conflict transformation and justify their approach;

- to define a system of goals for innovation management;

- to develop the innovation management objective accomplishment stages at an industrial enterprise;

- to propose a structure and a way to form a corporate introduction base;

- to calculate the economic effect from the introduction of the integrated innovation management activities at industrial enterprises.

Results. We propose a structure and techniques to create a corporate introduction base, the basis of which is a set of job assignments and, corresponding to each job assignment, a set of individual and group novelties or knowledge about them. Each task corresponds to a specific objective of innovation management.

Job assignments, as well as individual and group novelties or knowledge about them, correspond to the levels of management (strategic, tactical and operational ones) and areas of the corporation.

Job assignments should be described on the basis of the following scheme: the first element is the place of this job assignment in the activity. The second element is the statement of the task, which consists of the formulation of the objectives for its implementation and output data. The third element is an indication of those regulated procedures that are required to complete the job assignment. A typical job assignment is a task that is generalized, typical for most professional situations. Obviously, professional activity consists of performing labor functions that require complex skills from a specialist, which require various innovations. But any typical task can be decomposed into a hierarchy of the subtasks, the low level of which consists of private subtasks. When forming job assignments, it is necessary to proceed from a typical job assignment, the implementation of which is preceded by training in solving particular problems. A private task is a task corresponding to an 
elementary professional situation. Tasks that can cover several elementary situations are defined as cross-cutting.

Job assignments that cover a large range of cross-cutting tasks are complex tasks. Complex tasks should cover the main content of a specialist's activity, provide possibility of transferring skills acquired in problem solving of one type to other types. For each job assignment, the formation of individual and group innovations is carried out, which are the results of transfer, algorithmic, creative innovation management.

The corporate introduction base includes two modules: an individual innovation base (IIB) and a group innovation base (GIB).

An individual innovation base is a set of individual professionals' innovations used to solve problems in their area of activity.

Group innovation base is a set of group innovations used by members of the professional community or working group in their professional activities.

The model of individual innovation base can be described by merging $W$ (multiple job assignments) and $X^{i}$ (multiple individual innovations)

$$
K^{i}=W \cup X^{i} .
$$

Multiple individual innovations on $i$-job assignment are described as $X_{i}^{I}$. Then multiple $X^{i}$ - individual innovations, formulated for all $n$-job assignments, will be determined as following

$$
X^{i}=\bigcup_{i=1}^{n} X_{1}^{I}
$$

Therefore, multiple individual professional innovations on $i$-assignment $X^{i}$ are put as

$$
X_{2}^{i}=C_{1}^{i} \cup T_{1}^{i} \cup M_{1}^{i} \cup S_{1}^{i} \cup N_{1}^{i},
$$

where individual innovations include: $C_{1}^{i}-$ conceptual; $T_{1}^{i}-$ technological; $M_{1}^{i}$ - methodological; $S_{1}^{i}-$ situational; $N_{1}^{i}-$ navigational.

Thus, individual methodological and navigational innovations $M_{1}^{i}$ and $N_{1}^{i}$ are expressed through individual methodological innovations by the stages of solving a job assignment (objective creation $-M_{i}^{i f}$, strategy $-M_{j}^{\tilde{n}}$, tactics $-M_{i}^{i t}$, outcomes $-M_{i}^{i p}$, control $\left.-M_{i}^{i k}\right)$ and through the individual navigational innovations by the stages of the strategy $\left(N_{i}^{i C}\right)$ and tactics $\left(N_{i}^{i t}\right)$.

Such a distribution of the innovations by the levels is connected with the definition of the innovations.

Methodological innovations - these are ways of solving a job assignment in a given organization, and they are considered at all levels of the problem solving.

Navigational innovations - these are examples of solving a job assignment, taken from the experience of other organizations and taking into account world scientific achievements. In this regard, they are considered only in a generalized form at the strategic and tactical stages of the task.

These innovations are represented by the formulas

$$
\begin{gathered}
M_{i}^{i}=M_{i}^{i f} \cup M_{i}^{i C} \cup M_{i}^{i t} \cup M_{i}^{i p} \cup M_{i}^{i k} ; \\
N_{i}^{i}=N_{i}^{i C} \cup N_{i}^{i t} .
\end{gathered}
$$

For a group innovation base, the model is built by analogy with the model of an individual innovation base, while the elements are not individual innovations, but group ones

$$
K^{r}=W \cup X^{r} .
$$

Multiple group innovations by the $i$-job assignment will be designated as $X_{i}^{r}$. Then multiple $X^{r}$ group innovations, formulated for all $n$-job assignments, will be determined by the formula

$$
X^{r}=\bigcup_{i=1}^{n} X_{i}^{r}
$$

Therefore, multiple $X_{i}^{r}$ - group innovations by $i$-job assignment we will represent as the formula

$$
X_{i}^{r}=C_{i}^{r} \cup T_{i}^{r} \cup M_{i}^{r} \cup S_{i}^{r} \cup N_{i}^{r},
$$

where group innovations include: $C_{i}^{r}$-conceptual; $T_{i}^{r}-$ technological; $M_{i}^{r}$ - methodical; $S_{i}^{r}$ - situational; $N_{i}^{r}-$ navigational.

Conceptual, technological, situational innovations are presented in the form of sets whose elements are separate inferences - innovation units.

Group, individual methodical innovations, which are a way to solve a problem, are written in the form of elements of innovations according to the stages of solving a job assignment:

$$
\begin{aligned}
& \text { objective formation }-M_{3}^{r f}, M_{3}^{i f} ; \\
& \text { strategy }-M_{j}^{r c}, M_{j}^{i c} ; \\
& \text { tactics }-M_{i}^{r t}, M_{i}^{i t} \text {; } \\
& \text { outcomes }-M_{i}^{r p}, M_{i}^{i p} \text {; } \\
& \text { control }-M_{i}^{r k}, M_{i}^{i k} . \\
& \qquad M_{i}^{r}=M^{r f}{ }_{3} \cup M^{r C} \cup M_{3}^{r t} \cup M^{r p} \cup M^{r k} . \\
& \qquad M_{i}^{i}=M_{i}^{i f} \cup M_{i}^{i C} \cup M_{i}^{i t} \cup M_{i}^{i p} \cup M_{i}^{i k} .
\end{aligned}
$$

Group and individual navigational innovations represent the other companies' positive experience in solving similar job assignments, so they are considered in two stages: strategy $\left(N_{i}^{r c} N_{i}^{i c}\right)$ and tactic $\left(N_{i}^{r t} N_{i}^{i t}\right)$

$$
\begin{aligned}
& N_{i}^{r}=N_{i}^{r c} \cup N_{i}^{r t} ; \\
& N_{i}^{i}=N_{i}^{i c} \cup N_{i}^{i t} .
\end{aligned}
$$

Consider methodological innovations in more detail. Many methodological group and individual innovations at the objective forming stage by the $i$-job assignment represent, respectively, a set of global goals

$$
M_{i}^{r f}=\left\{y_{i l}, \ldots, y_{i m}\right\}, \quad M_{i}^{i f}=\left\{x_{i l}, \ldots, x_{i m}\right\} .
$$

At the stage of strategy, many methodological group and individual innovations by the $i$-job assignment are multi global sub-problems

$$
M_{i}^{r c}=\left\{q_{i l}^{r}, \ldots, q_{i m}^{r}\right\}, \quad M_{i}^{i c}=\left\{q_{i l}^{i}, \ldots, q_{i m}^{i}\right\},
$$

where $q_{i g}^{r}, q_{i g}^{i}$ are global sub-problems, respectively, formed by a group or individually, each global sub-problem is presented as a union of a set consisting of one global goal and a set of global initial data. Let us write down the global sub-problems formed by the group and the individual

$$
\begin{aligned}
& q_{i g}^{r}=\left\{y_{i g}^{r}\right\} \cup\left\{X_{i g 1}^{r}, \ldots, X_{i g r}^{r}\right\} ; \\
& q_{i g}^{i}=\left\{y_{i g}^{i}\right\} \cup\left\{X_{i g 1}^{i}, \ldots, X_{i g r}^{i}\right\},
\end{aligned}
$$

where $\left\{y_{i g}^{r}\right\}$ is a global goal, created by the group; $\left\{X_{i g 1}^{r}, \ldots, X_{i g r}^{r}\right\}$ is a global output generated by the group; $\left\{y_{i g}^{r}\right\}$ is a global goal created by the individual; $\left\{X_{i g 1}^{r}, \ldots, X_{i g r}^{r}\right\}$ is a global output generated by the individual.

At the tactical stage, the solution of each global subtask is specified and for each sub-problem there is a set of sub-problems of the $1^{s t}, 2^{\text {nd }}$ and $3^{\text {rd }}$ levels for the methodological group innovations $\left\{q_{i l}^{r l}, \ldots, q_{i k_{1}}^{r l}\right\},\left\{q_{i l}^{r 2}, \ldots, q_{i k_{2}}^{r 2}\right\},\left\{\left\{q_{i l}^{r k}, \ldots, q_{i k_{k}}^{r k}\right\}\right.$ and methodological individual innovations $\left\{q_{i l}^{i l}, \ldots, q_{i k_{1}}^{i l}\right\}, \quad\left\{q_{i l}^{i 2}, \ldots, q_{i k_{2}}^{i 2}\right\}$, $\left\{q_{i l}^{i k}, \ldots, q_{i k_{k}}^{i k}\right\}$ 


$$
\begin{aligned}
& M_{i l}^{r t}=\left\{q_{i l}^{r l}, \ldots, q_{i k_{1}}^{r l}\right\} \cup\left\{q_{i l}^{r 2}, \ldots, q_{i k_{2}}^{r 2}\right\} \cup \ldots \cup\left\{q_{i l}^{r k}, \ldots, q_{i k_{k}}^{r k}\right\} \\
& M_{i}^{i t}=\left\{q_{i l}^{i l}, \ldots, q_{i k_{1}}^{i l}\right\} \cup\left\{q_{i l}^{i 2}, \ldots, q_{i k_{2}}^{i 2}\right\} \cup \ldots \cup\left\{q_{i l}^{i k}, \ldots, q_{i k_{k}}^{i k}\right\}
\end{aligned}
$$

At the stage of obtaining outcomes, multiple methodological group and individual innovations for each job assignment will be written as

$$
\begin{aligned}
& M_{i}^{r p}=\left\{e_{i l}^{r}, \ldots, e_{i m}^{r}\right\} ; \\
& M_{i}^{i p}=\left\{e_{i l}^{i}, \ldots, e_{i m}^{i}\right\},
\end{aligned}
$$

where $e_{i g}^{r}, e_{i g}^{i}$, are separate outcomes.

A set of methodological group and individual innovations at the control stage is a set of conclusions on the correspondence of the obtained results to the desired

$$
\begin{aligned}
& M_{i}^{r k}=\left\{u_{i l}^{r}, \ldots, u_{i k}^{r}\right\} ; \\
& M_{i}^{i k}=\left\{u_{i l}^{i}, \ldots, u_{i k}^{i}\right\} .
\end{aligned}
$$

Navigational innovations are presented at the strategy and tactics stages in a similar way [18], taking into account the fact that all formed elements are not the outcome of this organization's activity, but the other organizations' positive reference experience $[19,20]$.

As a model for the corporate innovation base formation, we will consider a logical cause-and-effect relationship, designated as " $\rightarrow$ ".

A feature of the causal relationship is that it shows the logic and order of the innovations formation. A general description of the cause-and-effect relationship, which accumulates a knowledge unit, is written as

$$
S ; L ; A \rightarrow B ; C,
$$

where $S$ is description of a situation class in which a causal relationship can be used, in our case it is a job assignment $\left(W_{j}\right)$; $L$ is a condition, when the causal relationship is updated, that is the procedure for entering innovations into the innovation base by the innovation management manager $\left(P_{i}\right) ; A$ is reason, or innovations obtained individually or in a group $\left(X_{i}\right)$; $B$ is consequence, or innovation accumulated in the innovation base $\left(R_{i}^{z}\right) ; C$ is an indication of the changes that need to be made to the elements of this causal relationship; in our case, this is a transition to the next knowledge (denoted as $i=$ $=i+1$ ) or to the next job assignment (denoted as $j=j+1$ ).

Given the above, the causal relationship of the innovation base formation will be written as

$$
W_{j} ; P_{i} ; X_{i} \rightarrow R_{i}^{x} ; i=i+1,
$$

to move to the next type of innovation;

$$
W_{j} ; P_{i} ; X_{i} \rightarrow R_{i}^{x} ; j=j+1,
$$

to move to the next job assignment.

Consider the accumulation of innovations based on causation for a single job assignment. Since it is the same for group and individual innovations, we will not designate them specifically. The cause-and-effect relationship of the conceptual innovations accumulation $C_{i}$ by the $i$-job assignments is presented as

$$
W_{j} ; P_{i} ; C_{i} \rightarrow R_{i}^{c} ; i=i+1 .
$$

The causal relationship of the technological innovations accumulation $T_{i}$ by $i$-job assignment will be presented as

$$
W_{j} ; P_{i} ; T_{i} \rightarrow R_{i}^{T} ; i=i+1 .
$$

The causal relationship of the methodological innovations accumulation $M_{i}$ by the $i$-job assignment will be presented as

$$
W_{j} ; P_{i} ; M_{i} \rightarrow R_{i}^{m} ; i=i+1 .
$$

Taking into account the fact that methodological innovations are considered at the stages of solving a job assignment, the above presented causal relationship consists of included causal relationships.

The causal relationship of the methodological innovations accumulation at the goal-setting stage is presented in the form

$$
W_{j} ; P_{i} ; M_{i}^{f} \rightarrow R_{i}^{f M} ; i=i+1 .
$$

The causal relationship of the methodological innovations accumulation at the strategic stage is presented in the form

$$
W_{j} ; P_{i} ; M_{i}^{c} \rightarrow R_{i}^{c M} ; i=i+1 .
$$

The causal relationship of the methodological innovations accumulation at the tactical stage is presented in the form

$$
W_{j} ; P_{i} ; M_{i}^{t} \rightarrow R_{i}^{t M} ; i=i+1 .
$$

The causal relationship of the methodological innovations accumulation at the outcome stage is presented in the form

$$
W_{j} ; P_{i} ; M_{i}^{p} \rightarrow R_{i}^{p M} ; i=i+1 .
$$

The causal relationship of the methodological innovations accumulation at the control stage is presented in the form

$$
W_{j} ; P_{i} ; M_{i}^{k} \rightarrow R_{i}^{k M} ; i=i+1 .
$$

The causal relationship of the situational innovations $S_{i}$ accumulation by the $i$-job assignment will be presented in the form

$$
W_{j} ; P_{i} ; S_{i} \rightarrow R_{i}^{s} ; i=i+1 .
$$

The causal relationship of the accumulation of the reference innovations $H_{i}$ by the $i$-job assignment will be presented in the form

$$
W_{j} ; P_{i} ; H_{i} \rightarrow R_{i}^{H} ; i=i+1 .
$$

The causal relationship of the accumulation of the navigational innovations $N_{i}$ by the $i$-job assignment will be presented in the form

$$
W_{j} ; P_{i} ; N_{i} \rightarrow R_{i}^{N} ; i=i+1 .
$$

Taking into account the fact that navigational innovations are presented at the strategy and tactics stages for solving job assignment, there are such causal relationships.

The causal relationship of the accumulation of navigational innovations at the strategy stage is presented in the form

$$
W_{j} ; P_{i} ; N_{i}^{c} \rightarrow R_{i}^{c N} ; i=i+1 .
$$

The causal relationship of the accumulation of navigational innovations at the tactics stage is presented in the form

$$
W_{j} ; P_{i} ; N_{i}^{t} \rightarrow R_{i}^{t N} ; i=i+1 .
$$

A feature of the innovation base is that these innovations are also formed taking into account various forms of innovation presentation.

There are homogeneous and complex forms of innovation presentation.

The collection of forms can be described by the following expression

$$
M_{1}=\{F, T, S, V, K, C\},
$$

where $F$ is formal presentation of innovations ( $F$-form); $T$ is text presentation of innovations ( $T$-form); $S$ is audio presentation of innovations (speech, sounds) form ( $S$-form); $V$ is visual presentation of innovation ( $V$-form); $K$ - kinestatic representation of innovations ( $K$-form); $C-$ complex presentation of innovations ( $C$-form).

With the help of the $F$-form, the content of formal laws, theorems, axioms is conveyed; through the $T$-form - the content of printed materials - articles, magazines, newspapers, books, patents, dissertations, reports, curricula, medical records 
of patients and other materials that do not contain mathematical expressions; using the $S$-form - the content of sound recordings, and so on; using the $V$-form - the content of visual images; with the help of the $K$-form - the content of actions, events. The $C$-form of presenting innovations combines several homogeneous forms at the same time, for example, text and auditory, kinestatic and visual, and so on. The complex form of innovation presentation is widespread, combining auditory and visual forms and is called the audiovisual form $-S V$-form. With the help of this form, the content of television and film materials is expressed - television programs, films, newsreels, and others.

The results we have obtained are aimed at improving innovation management methods as a holistic mechanism in the context of transfer, algorithmic and creative approaches in order to accumulate and integrate innovations of corporations to improve the efficiency of their activities.

Conclusions. A model of an integrative approach to innovative management in corporate entities with a mathematical foundation has been developed. Our proprietary model of the innovative management is based on an integration approach. In modern corporate structures, innovation is divided into groups of independent properties. An innovation management system, if it exists, is considered as an independent system that has its own set of goals that are not integrated into the goals of the corporation itself. We consider the innovative management objectives in the integrated structure as the realization of the corporation goals, where the innovation management processes are horizontally and vertically integrated according to the business processes. In our opinion, the innovation management is based on three approaches: transfer, algorithmic and creative management. Transfer management is intended to manage and teach various forms of innovation transfer. Algorithmic management involves the management of innovative processes that are algorithmic in nature. These processes include the processes of finding new sources of innovation, including employees and external contractors who have the necessary innovations. Creative management, in turn, involves working with non-formalized or poorly formalized processes and includes the innovations creation and improvement

To implement our proprietary methodology, it is proposed to use an algorithm that consists of three stages, which are implemented sequentially:

- firstly, the corporate goals hierarchy formation, based on expert and creative decision-making methods in all areas of activity (production, marketing, finance, human resource management, information technology support) and management levels (strategic, tactical, operational ones);

- secondly, identification of the innovation management's initial objectives necessary for the implementation of the multiple corporate goals for the relevant areas of activity and levels of management;

- thirdly, identifying the relationship between the innovation management objectives, existing innovations and their sources, based on the above approaches to innovation management. The resulting innovations or knowledge about them are adapted to the objectives selected above and accumulated in the corporate database.

A system for evaluating the economic efficiency of innovation management in corporations is proposed. To calculate economic efficiency when using the innovation management system, it is necessary to assess the revenue growth by increasing the total amount of innovation for all types of corporate governance.

The practical significance of the results is that they can be applied in corporate integration structures to increase economic efficiency, making a profit from innovation.

\section{References.}

1. Chukurna, O., Nitsenko, V., Kralia, V., Sahachko, Y., Morkunas, M., \& Volkov, A. (2019). Modelling and Managing the Effect of Transferring the Dynamics of Exchange Rates on Prices of Machine-Building Enterprises in Ukraine. Polish
Journal of Management Studies, 19(1), 117-129. https://doi. org/10.17512/pjms.2019.19.1.09.

2. Johnson, J. (2021). Does a Theory of Everything Exist? Philosophy and Cosmology, 26, 132-147. https://doi.org/10.29202/ phil-cosm/26/11.

3. Andriushchenko, K., Datsii, O., Aleinikova, O., Abdulla Alebri Mohamed, \& Ali Alhemeiri Mohammed (2019). Improvement of the water resources management system at the territorial level. Problems and Perspectives in Management, 17, 421-437. http://doi.org/10.21511/ppm.17(3).2019.34.

4. Baharun, R., Jing Mi, T., Streimikiene, D., Mardani, A., Shakeel, J., \& Nitsenko, V. (2019). Innovation in healthcare performance among private brand's healthcare services in small and medium-sized enterprises (SMEs). Acta Polytechnica Hungarica, 16(5), 151-172. https://doi.org/10.12700/APH.16.5.2019.5.9.

5. Terepyshchyi, S., \& Khomenko, H. (2019). Development of Methodology for Applying Non-Violent Conflict Resolution in Academic Environment. Future Human Image, 12, 94-103. https://doi.org/10.29202/fhi/12/8.

6. Tang, W., \& Qiu, X. (2020). Construction of Law-based Government in the Context of Counteraction to COVID-19. Ukrainian Policymaker, 6, 74-84. https://doi.org/10.29202/up/6/8. 7. Basova, A. V. (2016). Development of accounting and analytical support for innovative processes in the management accounting system. Investments. Building. Real Estate, 1(16), 11-20.

8. Raišienè, A. G., Yatsenko, O., Nitsenko, V., Karasova, N., \& Vojtovicova, A. (2019). Global dominants of Chinese trade policy development: Opportunities and threats for cooperation with Ukraine. Journal of International Studies, 12(1), 193207. https://doi.org/10.14254/2071-8330.2019/12-1/13.

9. Bezzubov, D., \& Pravotorova, O. (2020). The Impact of Transnational Corporations on the Regulatory Framework for the World Market for Space Services and Technologies. Advanced Space Law, 6, 4-12. https://doi.org/10.29202/asl/6/1. 10. Nitsenko, V., Chukurna, O., Mardani, A., Streimikis, J., Gerasymchuk, N., Golubkova, I., \& Levinska, T. (2019). Pricing in the Concept of Cognitive Marketing in the Context of Globalization: Theoretical, Methodological and Applied Aspects. Montenegrin Journal of Economics, 15(4), 131-147. https://doi.org/10.14254/1800-5845/2019.15-4.10.

11. Sameer, Y.M. (2018). Innovative behavior and psychological capital: Does positivity make any difference? Journal of Economics \& Management, University of Economics in Katowice, 32(2), 75-101.

12. Bommier, A., Bretschger, L., \& Le Grand, F. (2017). Existence of equilibria in exhaustible resource markets with economies of scale and inventories. Economic Theory, 63(3), 687721. https://doi.org/10.1007/s00199-016-0956-5.

13. Olson, D., \& Wu Dash, D. (2017). Enterprise Risk Management Models. Springer-Verlag Gmb HGermany. https:// doi.org/10.1007/978-3-662-53785-5.

14. Nitsenko, V., Kotenko, S., Hanzhurenko, I., Mardani, A., Stashkevych, I., \& Karakai, M. (2020). Mathematical Modeling of Multimodal Transportation Risks. In: Ghazali R., Nawi N., Deris M., \& Abawajy J. (Eds.) Recent Advances on Soft Computing and Data Mining. SCDM 2020. Advances in Intelligent Systems and Computing, (pp. 439-447). Springer, Cham. https://doi.org/10.1007/978-3-030-36056-6 41.

15. Arsawan, I. W. E., Koval, V., Rajiani, I., Rustiarini, N. W., Supartha, W. G., \& Suryantini, N.P.S. (2020). Leveraging knowledge sharing and innovation culture into SMEs sustainable competitive advantage. International Journal of Productivity and Performance Management. https://doi.org/10.1108/ IJPPM-04-2020-0192.

16. Rekova, N., Dolozina, I., Nitsenko, V., Zaitsev, Y., \& Zamlynskyi, V. (2018). Budgetary revenue structure at central level of public administration in the federal countries. Administratie si Management Public, 30, 37-50. https://doi. org/10.24818/amp/2018.30-03.

17. Smoliy, L., Revutska, A., \& Novak, I. (2018). Influence of innovation factor in economic dynamics in Europe. Marketing 
and Management of Innovations, 1, 247-258. https://doi. org/10.21272/mmi.2018.1-18.

18. Klius, Y. (2015). Corporate management system innovations: the formulation of this development. Lisichansk: Kit-L.

19. Nitsenko, V., Kotenko, S., Hanzhurenko, I., \& Ingram, K. L. (2020). Determination of Weight Coefficients for Stochastic and Fuzzy Risks for Multimodal Transportation. Journal of Physics: Conference Series, 1529, 032007. https:// doi.org/10.1088/1742-6596/1529/3/032007.

20. Kotenko, S., Nitsenko, V., Hanzhurenko, I., \& Havrysh, V. (2020). The Mathematical Modeling Stages of Combining the Carriage of Goods for Indefinite, Fuzzy and Stochastic Parameters. International Journal of Integrated Engineering, 12(7), 173-180. https://doi.org/10.30880/ijie.2020.12.07.019.

\section{Розробка інтеграційного підходу до управління інноваційною діяльністю на промислових підприємствах в умовах постконфліктної трансформації}

\section{Ю. І. Клюс ${ }^{1}$, С. А. Івченко ${ }^{1}$, Ю. А. Івченко ${ }^{1}$, М. Ю. Манухіна ${ }^{1}$, М.А. Мельнік ${ }^{2}$}

1 - Східноукраїнський національний університет імені Володимира Даля, м. Сєвєродонецьк, Україна, e-mail: docentklus@gmail.com

2 - Сєвєродонецький інститут Міжрегіональної Академії управління персоналом, м. Сєвєродонецьк, Україна

Мета. Розробка інтеграційного управління інноваціями на основі створення корпоративної інноваційної бази на промислових підприємствах в умовах постконфліктної трансформації.

Методика. У ході дослідження використовувалися методи теоретичного узагальнення, порівняння, синтезу, аналізу для виявлення загальних принципів і визначення основних категорій дослідження.

Результати. Розроблена модель інтеграційного підходу до інноваційного менеджменту на промислових підприємствах. У сучасних корпоративних структурах інновації розділені на групи за своїми незалежним властивостями. Система управління інноваціями, якщо вона існує, розглядається як незалежна система, що має власний набір цілей, не інтегрованих у цілі самої корпорації. У роботі розглянуті цілі інноваційного менеджменту в інтегрованій структурі як реалізація цілей корпорації, де процеси управління інноваціями інтегровані по горизонталі і вертикалі відповідно до бізнес-процесів. Управління інноваціями засноване на трьох підходах: трансферному, алгоритмічному та креативному.

Наукова новизна. У роботі пропонується авторська методологія управління інноваціями з використанням системи методологічних підходів (алгоритмічне управління, трансферне управління, креативне управління), заснованих на виявлених за допомогою математичних моделей процесах управління інноваціями на промислових підприємствах в умовах постконфліктної трансформації. У ході дослідження розроблені:

- авторський підхід до формування цілей управління інноваціями на промислових підприємствах в умовах постконфліктної трансформації, заснований на восьми ключових просторах, із виділенням п'яти груп цілей: фінансових, виробничих, маркетингових, людських, управління ресурсами, інформаційної підтримки;

- система цілей управління інноваціями з підсистемою завдань управління інноваціями в області фінансової діяльності, процесу виробництва, маркетингу, управління людськими ресурсами та інформаційно-технічної підтримки.

Практична значимість. Практичне значення результатів полягає в тому, що вони можуть бути застосовані в корпоративних інтеграційних структурах для підвищення економічної ефективності, отримання прибутку від інновацій.
Ключові слова: інноваційна діяльність, про-промислове підприємство, постконфліктна трансформація, оцінка, показники

\section{Разработка интеграционного подхода}

\section{к управлению инновационной деятельностью на промышленных предприятиях в условиях постконфликтной трансформации}

\author{
Ю. И. Клюс ${ }^{1}$, Е. А. Ивченко ${ }^{1}$ Ю. А. Ивченко ${ }^{1}$, \\ М. Ю. Манухина ${ }^{1}$ М.А. Мельник ${ }^{2}$
}

1 - Восточноукраинский национальный университет имени Владимира Даля, г. Северодонецк, Украина, e-mail: docentklus@gmail.com

2 - Северодонецкий институт Межрегиональной Академии управления персоналом, г. Северодонецк, Украина

Цель. Разработка интеграционного управления инновациями на основе создания корпоративной инновационной базы на промышленных предприятиях в условиях постконфликтной трансформации .

Методика. В ходе исследования использовались методы теоретического обобщения, сравнения, синтеза, анализа для выявления общих принципов и определения основных категорий исследования.

Результаты. Разработана модель интеграционного подхода к инновационному менеджменту на промышленных предприятиях. В современных корпоративных структурах инновации разделены на группы по своим независимым свойствам. Система управления инновациями, если она существует, рассматривается как независимая система, имеющая собственный набор целей, не интегрированных в цели самой корпорации. В работе рассмотрены цели инновационного менеджмента в интегрированной структуре как реализация целей корпорации, где процессы управления инновациями интегрированы по горизонтали и вертикали в соответствии с бизнес-процессами. Управление инновациями основано на трех подходах: трансферном, алгоритмическом и креативном.

Научная новизна. В работе предлагается авторская методология управления инновациями с использованием системы методологических подходов (алгоритмическое управление, трансферное управление, креативное управление), основанных на выявленных с помощью математических моделей процессах управления инновациями на промышленных предприятиях в условиях постконфликтной трансформации. В ходе исследования разработаны:

- авторский подход к формированию целей управления инновациями на промышленных предприятиях в условиях постконфликтной трансформации, основанный на восьми ключевых пространствах, с выделением пяти групп целей: финансовых, производственных, маркетинговых, людских, управления ресурсами, информационной поддержке;

- система целей управления инновациями с подсистемой задач управления инновациями в области финансовой деятельности, процесса производства, маркетинга, управления человеческими ресурсами и информационно-технической поддержки.

Практическая значимость. Практическое значение результатов заключается в том, что они могут быть применены в корпоративных интеграционных структурах для повышения экономической эффективности, получения прибыли от инноваций.

Ключевые слова: инновационная деятельность, промышленное предприятие, постконфликтная трансформация, оценка, показатели

Recommended for publication by L.A. Kostyrko, Doctor of Economic Sciences. The manuscript was submitted 16.11.20. 